\title{
Pre-reading Assignments: Promoting Comprehension of Classroom Textbook Materials
}

\author{
Sami A. Al-wossabi* \\ English Department, Faculty of Arts and Humanities, Jazan University, Jazan, Saudi Arabia \\ *Corresponding author: sami_ed@hotmail.com
}

Received August 22, 2014; Revised September 02, 2014; Accepted September 10, 2014

\begin{abstract}
Reading is seen today as one of the most fundamental skills to acquire knowledge in any discipline. The present study is an attempt to highlight such importance for EFL Saudi learners at Jazan University. It investigates the influence of pre-reading assignments on maximizing Saudi EFL learners' comprehension of classroom textbook materials. In this regard, 60 learners were randomly assigned to experimental and control groups designed to qualify the above statement. Participants in both groups were introduced to language acquisition learning theories for threemonth period. However, in the experimental group, learners were instructed via the use of pre-reading assignments. An unpaired sample of T- test is used for this study to determine if there is a significant difference of achievement for subjects introduced to pre-reading assignments. The results of the study revealed that there is a strong correlation between the use of pre-reading assignments and better comprehension of classroom learning materials. The study concludes with a rationale to empower and utilize the use of pre- reading strategies in the EFL Saudi learning context.
\end{abstract}

Keywords: pre-reading assignments, comprehension, classroom textbook materials, reading strategies, prior knowledge, content area

Cite This Article: Sami A. Al-wossabi, "Pre-reading Assignments: Promoting Comprehension of Classroom Textbook Materials." American Journal of Educational Research, vol. 2, no. 9 (2014): 817-822. doi: 10.12691/education-2-9-17.

\section{Introduction}

There has not been much discussion in the academia about the use of pre-reading activities in the EFL context. Few articles though addressed the benefits of using prereading activities for EFL learners [3,32,41,42]. This could be attributed to the difficulty that educators face when asking students to perform and accomplish tasks of their own in EFL classrooms. For instance, the researcher observed that many Saudi EFL learners appear to be reluctant and even resistant to be involved in new teacherinitiated activities. Teachers may also come to realize that it is better not to force such activities on students as long as learners do not feel comfortable with extra and new learning loads. One reason that lies behind such resistance is that learners have been following a particular learning scenario based momentously on memorizing prescribed extracts of information given by their teachers rather than on understanding, thinking, and acting.

Unfortunately, it has been also observed that such phenomenon is persistent and seems to receive great approval from many teachers as well as learners. Teachers are used to and sometimes forced to prepare written brief notes of the content area. Students, on the other hand, study the notes one week before examination, memorize them mostly without knowing the meaning of their content and usually pass with distinction. Therefore, in the above learning context, success in learning depends on having powerful memory rather than understanding the content area being studied.

In a university setting where most EFL learners range between absolute beginners and high intermediate with levels in between, maximizing the role of pre-reading activities appear to be one of the best teaching and learning practices to ensure positive and solid engagements with textbook materials $[3,13,41]$. EFL Saudi learners have difficulties coping with different reading texts particularly those related to materials in Language Acquisition, Applied Linguistics, Discourse Analysis, etc. Such textbooks are heavily laden with difficult and vague lexical items [23,30]. For instance, according to my teaching experience, the word "Interlanguage" is difficult to be conceptualized by Arab EFL learners as there is no such counterpart or equivalent in Arabic language. Such words are target words for EFL learners majoring in English and as such need to be learnt for subsequent use in future contexts. Failure to understand particular linguistic terms demotivate learners and cause them to act passively in most of their language classes. They do feel disappointed particularly if the learning material exceeds by far their background knowledge and their ability to understand the overall meaning of texts.

The present research is not blaming teachers or students for such unproductive learning environment. The researcher himself has been taking part in the same teaching context and using similar teaching criteria for 
two semesters. In the meantime, the researcher has been incorporating several teaching strategies to speculate on the best practices that could enhance the students' learning experiences. Hence, the present study aims at experimentally investigating the extent to which pre-reading assignments can help learners better understand their learning materials and be able to develop good knowledge of the content areas being studied.

\section{Literature Review}

\subsection{L2 Reading: A Cognitive Process}

Many L1 and L2 research highlights the importance of reading as one of the most important skills in successful leaning of languages. Reference [38] stated that "reading is the most important activity in any language class, not only as a source of information and a pleasurable activity, but also as a means of consolidating and extending one's which are knowledge of the language” (p.147). According to [21], reading is "the ability to read the written language at a reasonable rate with good comprehension has long been recognized to be as important as oral skills, if not more important" (p.1). A more comprehensive definition of L2 reading is provided by [34] (p.54),

Reading involves interactions among the reader's Interlanguage competence (e.g. incomplete, fragmented or not fully-developed linguistic, strategic discourse and sociolinguistic competence), personal characteristics (e.g., learning and cognitive style, gender, motivation and volition, socioeconomic status, educational levels) and external contexts (e.g. topics, text characteristics, reasons to read, stakes of reading, time constraints)

Reading is unanimously defined in SLA research as an interactive cognitive processing of text information in which readers interact with text and author's perspectives. During reading process, readers repetitively form their own hypotheses and predictions and use their prior knowledge of language to construct meaning [12,45]. Therefore, readers are highly involved in extracting and constructing meaning from the text, and relatively reflecting on the ideas displayed on the text. As [27] put it out,

"A person is unlikely to comprehend a text by accident. If the person is not aware of the text, not attending to it, not choosing to make meaning from it, or not giving cognitive effort to knowledge construction, little comprehension occurs” (p. 199).

The interaction between readers and the written texts is characterized by different cognitive processes, such as, negotiating the meaning of the texts, using prior background knowledge, processing of lexical items and many other reading strategies are taking place simultaneously during the interplay between the reader and texts $[5,26,27,28,29,30]$. Many conscious and unconscious strategies are involved in the reading processes and aid readers to facilitate their efforts to decode a text, understand words and construct meaning [2,24].

\subsection{Reading Strategies}

SLA researchers have classified two main broad categories for reading strategies, namely cognitive and metacognitive strategies. Reference [33] explained that, "metacognitive strategies involve planning, monitoring, and evaluating that take place before, during, and after any thinking act such as reading... In contrast cognitive strategies refer to integrating new material with prior knowledge. Cognitive strategies that students use to acquire, learn, remember, retrieve and understand the material while reading include rehearsal, elaboration, and organizational strategies" (p. 190).

The definition above indicates that cognitive strategies are necessary for performing the reading task while metacognitive strategies are necessary in understanding how the readers plan and perform the task. Both strategies appear to be interrelated and can be used interchangeably. This is why it has been concluded by many L2 reading researchers that metacognitive strategies have a direct influence on cognitive strategies in L2 learning, use or performance ( e.g. [4,6,14,17,22,36]).

Reference [5] investigated the differences in the use of the reading strategies used by adult second language learners. Both high and low scoring readers more or less used similar strategies while answering the comprehension questions. However, Anderson found that high scoring students were more capable of tailoring and applying reading strategies than that of low scoring readers. Reference [43] noted that successful readers use reading strategies different from that of unsuccessful readers. Successful readers tended to use metacognitive strategies such as planning for learning, monitoring the process and self-evaluating learning after the tasks.

\subsection{Extensive/intensive Reading and L2 Achievement}

The literature is abundant with work done to probe the correlation between extensive/intensive reading and L2 achievement (e.g. [7,19,28,35,37,39])

According to reference [11], "extensive reading... generally involves rapid reading of large quantities of material or longer readings (e.g., whole books) for general understanding, with the focus generally on the meaning of what is being read than on the language." (pp. 49-50). Reference [19] found that extensive reading aids L2 learners focus more on meaning rather than on form and thus can have a high intrinsic motivation if the content interests them. Reference [19] suggested that extensive reading involves extensive input of meaningful prints which will in turn give rise to noticeable language input. Reference [31] also found extensive reading to be effective in enhancing second language proficiency as it aids the learners to progress at their own pace and gives them the freedom to choose the content area of reading.

Reference[8] explained that intensive reading is "a classroom-oriented activity in which students focus on the linguistic or semantic details...grammatical forms, discourse markers, and other surface structure details for the purpose of understanding” (p. 373). " Reference [35] found that better L2 reading ability along with topic familiarity led to greater receptive ability of lexical items. Reference [39] found a significant effect of intensive reading on L2 grammar development when it was associated with discussions suggesting a possible effect of interactive activities on grammar acquisition.

\subsection{Pre-reading and Comprehension}


According to schema theory [40] the process of comprehending a text is interpretive and that involves the reader's background knowledge and the text itself. Reference [18] stated that "the mind stimulated by key words or phrases in the text or by the context activates a knowledge schema” (p. 69). Reference [44] argued, with reference to the schema theory, that reading could be thought of as understanding process that involves three stages (pre-reading, while-reading and post-reading). Thus, the second language learner must rely on preexisting schemata to attain appropriate interpretation to the text in hand. The importance of the utilization of prior knowledge or schema was well addressed by [1],

"A more correct statement of the role of background knowledge would be that comprehension is the use of prior knowledge to create new knowledge. Without prior knowledge, a complex object, such as a text, is not just difficult to interpret: strictly speaking, it is meaningless" (p. 37).

However, with regard to the EFL/ESL learning contexts, "some students' apparent reading problems may be problems of insufficient background knowledge" [13], (p. 245). Thus, EFL learners' reading problems could be thought to be topic-related, particularly when it comes to learning lexical items not within the student's area of knowledge. It has been suggested that 'narrow reading' or interest may improve the situation [15]. It would then seem more suitable to prepare students by "helping them build background knowledge on the topic prior to reading, through appropriate pre-reading activities" [13], (p. 245).

Pre-reading activities have been considered as effective learning tools to better comprehend reading texts and to avoid possible failure in understanding and extracting information during the reading processes. They are commonly used to prepare students to understand what they are about to read. Many SLA studies have found pre-reading activities as facilitative for comprehension of texts as it links the learner's prior knowledge with understanding the text in hand (e.g. [9,10,16,29,42]). Reference [16] claimed that such activities are challenging and motivating in the sense that they challenge students to recall their previous knowledge. [16] argued that the aim of such activities is to prepare students for understanding the reading text and as a result motivate them to read the passage. Reference [37] called pre-reading activities enabling activities as they elicit prior knowledge, provide background and focus attention. They pointed out that such experiences involve understanding the purposes for reading and building the necessary knowledge needed for dealing with the content and the structure of the material.

Narrowing towards the focus of the present study, intensive reading seems to be a more appropriate approach to be incorporated in the above teaching situation. This is because the aim is to study the content and to build more language knowledge of the content area rather than simply practice the skill of reading. Following an intensive reading approach, the use of pre-reading activities could be seen as the fastest way to build up Saudi EFL learners' vocabulary knowledge of the subject area [25,31]. Students would also be able to develop positive attitudes towards the content knowledge and its accompanying lexical items [16]. Additionally, pre-reading activities of difficult materials would foster EFL learners to develop strategies for dealing with texts that are too hard to read and understand comfortably in classroom.

\section{Methodology}

\subsection{Participants}

The participants were 60 third year male students enrolled in a language acquisition course in level (5), at the English department, Jazan University, 2013. All subjects have been taking the same language courses. Their proficiency levels ranged from low intermediate to high intermediate. Thirty students were assigned in the control group with no treatment and the other half were assigned in the experimental group where they were introduced to pre-reading activities as to prepare them for the reading texts related to key concepts in language acquisition.

\subsection{Procedure}

In finding out the influence of pre-reading assignments on learners' comprehension of classroom reading materials, the present research conducted an experimental study compromised of two groups; one was controlled and the other was experimental. Participants in the control group were given instructions following the current teaching criteria where learning takes place only in class. Participants in the experimental group were instructed via the use of pre-reading assignments that should be accomplished prior to classroom discussions. The language content area on which the participants were instructed was based on thematic units about first/second language acquisition concepts. The textbook used was Second Language Acquisition [20]. The period for following up the participants in both groups was three months.

To qualify the research inquiry, a single objective posttest was conducted by the end of the three months period. A pretest was not applicable in the present study, as the participants had zero knowledge of the subject area. That is to say, it was their first time to be introduced to concepts in the area of language acquisition. The posttest symbolized a comprehension test that comprised true/false items. The true/false statements included challenging statements to ensure the validity of the test construct and the test reliability of attaining similar results of students' subsequent achievement. There were 20 items and were weighed with two marks each. Then the raw scores were converted into percentiles. All items were carefully designed to cover classroom materials in language acquisition. Participants in the experimental and control groups have been trained on using True/False questions on aspects of language acquisition. Two quizzes were given to both groups during the three-month period of the study. To minimize the process of guessing answers, cheating, or leniency, participants were required to correct the false statements and provide plausible information to arrive at the standard score. Further, test scores were part of their classwork and were added to their overall score of the course.

In one session, the comprehension test was given to all subjects in the experimental group and the control group as well. Half an hour was devoted to participants to decide on the true statements and correct the false ones. All items addressed issues in first/second language acquisition to test students' understanding of the subject matter.

\subsection{Instrument}


An unpaired sample of T- test is used for this study to determine if there is a significant difference of achievement for subjects introduced to pre-reading activities. The independent t-test is also used to find the mean difference between performances of the two groups

\subsection{Data Analysis and Results}

The data that were gathered included 60 reading comprehension scores of participants involved in both the experimental and control group. As shown in Table 1, with regard to the $\mathrm{P}$ value and its statistical significance, the two-tailed $\mathrm{P}$ value is less than 0.0001. By conventional criteria, this difference is considered to be statistically significant.

Table 1. Independent samples test for reading comprehension

\begin{tabular}{cccccc}
\hline Groups & T-value & N & Mean & STD. Deviation & STD. Error Mean \\
\hline Experimental Group & 15.15 & 30 & 16.4 & 2.25 & 0.4108 \\
\hline Control Group & 15.15 & 30 & 7.3 & 2.4 & 0.4382 \\
\hline
\end{tabular}

As it is shown in Table 1, the observed ratio of T-value 15.15 is greater than the expected one at the at 0.01 level, this means that the difference between the groups is greater than the value required to reject the null hypothesis at the 0.01 level of significance. According to Table 1, the mean difference of group one minus group two equals 9.1. This significant difference between the experimental group and the control group indicates that participants who were instructed via pre-reading activities were significantly superior in terms of comprehension of the subject matter. It is obvious then that participants in the experimental group outperformed their partners in the control group. Such findings indicate the powerful drive of pre-reading activities in maximizing the learners' ability to comprehend and retain difficult concepts in language acquisition.

One interesting observation throughout the three months period is that students in the control group were not totally involved in the learning process of the subject matter and subsequently little commitment if any have been seen on their part. Students seemed to lose interest holding on the belief that the subject being studied was difficult and beyond their reach. On the other end of the continuum, learners in the experimental group have been taking responsibility of their learning with the help of prereading activities which kept them motivated and ever ready to absorb new thoughts and ideas of the content area.

Indeed, taking part in such activities was not an easy task. However, as soon as students felt the immediate effect of the pre-reading activities on their comprehension of the subject matter, they showed full involvement and total commitment in learning and participating in classroom discussions.

\section{Rationale for Using Pre-reading Assignments}

In the above learning context, learners appear to be low readers as commented by many language educators. Such remark has some truth in it. However, what worsen the situation is the presence of teacher -centered classes where learners are usually passive and have no role except for taking quizzes and exams that are often hinted at in advance.

Saudi EFL learners have no reading responsibilities to prepare them to comprehend what they are reading. As a result, they lose interest over time and become passive in class. Pre-reading assignments are suggested in the present paper to promote understanding of the content areas by activating learners' prior knowledge to connect what they know to new information being presented. Moreover, prereading assignments will provide EFL Saudi learners with information about the text and thus arouse their curiosity and enthusiasm to discover and locate new information necessary to build up their new knowledge of the content area. Additionally, pre-reading will maximize their learning autonomy that is crucial for enhancing their language competencies. What follows is an account for the rationale in terms of specific/general objectives and recommendations that need to considered prior to using pre-reading assignments in the Saudi EFL context.

\subsection{General Objectives}

- To enable Saudi EFL learners be part of the learning processes of English language.

- To keep them motivated throughout their degree course.

- To help them acquire appropriate knowledge of Applied Linguistics and its applications.

- To develop their learning autonomy.

\subsection{Specific Objectives:}

- Exploring and recalling prior knowledge that is relevant to the text.

- Setting a purpose / purposes for reading classroom materials.

- Visualizing the text to draw appropriate inferences.

- Previewing the text to get a sense of the structure and content

- Providing students with appropriate guidelines before reading.

- Establishing connections between their prior knowledge and what they are reading.

- Building students' confidence to explore complex texts.

- Monitoring their understanding of the text.

\subsection{Recommendations}

Recommendations are written with the Saudi EFL situation in the mind considering factors such as, learners' level, learners' needs, content area, background knowledge, etc. The recommendation are also the outcomes of the three-month teaching experience using pre-reading assignments with Saudi EFL learners.

\subsubsection{Assignments}

- Pre-reading could take place after a considerable amount of in class training. 
- Pre-reading should be designed to ensure that all students have a basic understanding of the subject matter not to cover the whole content of classroom textbook.

- Pre-reading assignments should first address the purpose of reading.

- They should be brief. A few statements in the form of an objective testing item will suffice, five or fewer is preferable. The shorter the assignment is, the more likely the students will actually read it.

- Pre-reading assignments should arouse students' curiosity to read the text.

- They should not often reveal information that students could obtain by simply reading the text.

- Assignments should not overwhelm students with open ended questions. Objective learning items are more appropriate particularly those in the form of true/false statements or multiple choice.

- Testing items such as true/false should require students to correct the false statements to ensure understanding of specific information.

- The assignment should create a clear connection between the reading and the expectations of the students for lecture.

\subsubsection{Teachers}

- At first, teachers should understand the difference between learners' level and the difficulty of the text and if learners have any background about the topic.

- Teachers should provide learners with context and necessary information (e.g. few statements) about unknown topics so they can cope with the difficult themes of the text.

- Teachers should assign marks for pre-reading quizzes. This would motivates students in keeping up with the reading over the entire term.

- Teachers should make sure that students have done the assignment themselves. They can choose some students randomly in every class and elicit some responses with regard to their assignments. Even if some students copy the assignments from their classmates, they have to read and understand them before class to be prepared in case they are asked by their teachers. Otherwise, such students should not be given marks.

- Teachers can use some of the students' responses in class to provoke discussion and elicit responses from other students. However, teachers should be careful to neither affirm nor deny students' responses.

- Teachers should provide context for unknown topics or difficult themes.

- Teacher should guide learners to deep understandings of key ideas of the reading texts particularly when it comes to specialized textbook in applied linguistics.

- No translation could be provided by teachers. It is the learners' task to translate difficult extracts of information or new terms.

\section{Conclusion}

Familiarizing learners with lexical items of specific domain and rich contexts via the use of pre-reading strategies proved to be effective in text comprehension. It is also more likely to contribute to long-term retrieval of word form and meaning and to productive use. This is because learners under such treatment are the discovery initiators of new meanings in classroom texts. As [23] put it out, "puzzling over problems with word meanings in context involves greater cognitive engagement, which helps subsequent recall both in highly variable and in rich, clear contexts" (pp. 319-320).

Understanding a text is therefore an active interplay between the reader and the text that primarily involves the search for the intended message. The learners' task then is to operate their prior linguistic knowledge on the printed materials following different strategies to arrive at the intended message. Hence, a good reader should be armed with a wide range of reading strategies in order to comprehend the text effectively and to solve the possible ambiguities he/she may encounter. Such reading strategies enable learners to be successful readers who know how to conceive of a task, how to make sense of what they read, and what to do when they do not understand.

To conclude, pre-reading assignments is a factor that could bring about a new trend in the Saudi EFL context as they can crucially contribute in the overall achievement of curricular goals and attainment of education. Such technique will ensure interactive classrooms where motivated students can actively seek knowledge, display intellectual curiosity, and find learning useful and enjoyable.

\section{Acknowledgments}

The present research was supported financially by the deanship of scientific research grant projects, Jazan University, Saudi Arabia.

\section{References}

[1] Adams, M., \& Bruce, B. (1982). Background knowledge and reading comprehension. In J.A. Langer \& M.T. Smith-Burke (Eds.), Reader meets author: Bridging the gap. A psycholinguistic and sociolinguistic perspective (pp. 2-25). Newark, DE. International Reading Association.

[2] Afflerbach, P., Pearson, P. D., \& Paris, S. G. (2008). Clarifying differences between reading skills and reading strategies. The Reading Teacher, 61, 364-373.

[3] Ajideh, P. (2006). Schema-theory based considerations on prereading activities in ESP textbooks. The Asian EFL Journal Teaching Articles, 16, 1-19.

[4] Anderson, N. J. (2005). L2 learning strategies. In E. Hinkel. (Ed), Handbook of research in second language teaching and learning (pp. 757-771). Mahwah, NJ: Lawrence Erlbaum.

[5] Anderson, N. J. (1991). Individual differences in strategy use in second language reading and testing. Modern Language Journal, 75, 460-472.

[6] Bachman, L.F., \& Palmer, A.S. (1996). Language testing in practice. Oxford: Oxford University Press.

[7] Beck, I. L., Perfetti, C. A., \& McKeown, M. G. (1982). The effects of long-term vocabulary instruction on lexical access and reading comprehension. Journal of Educational Psychology, 74, 506-521.

[8] Brown, H. D. (2007). Teaching by principles: An interactive approach to language pedagogy (pp. 357-389). Englewood Cliffs, NJ: Prentice Hall Regents.

[9] Brown, H. D. (1994). Teaching by principles: An interactive approach to language pedagogy. Upper Saddle River, Prentice Hall Regents. 
[10] Brown, C. (1993). Factors affecting the acquisition of vocabulary. In T. Huckin, M. Haynes \& J. Coady (Eds.), Second language reading and vocabulary (pp. 263-286). Norwood, NJ :Ablex.

[11] Carrell, P. L., \& Carson, J. G. (1997). Extensive and intensive reading in an EAP setting. English for Specific Purposes, 16, 4760.

[12] Carrell, P. L., (1989). Meta cognitive awareness and second language reading. Modern Language Journal, 73, 121-134.

[13] Carrell, P.L. (1988b). Interactive Text Processing: Implications for ESL/Second Language Reading Classrooms. In P.L., Carrell, J. Devineand, \& D.E. Eskey (Eds.), Interactive Approaches to Second Language Reading. Cambridge: CUP.

[14] Carrell, P.L., Devine, J. \& Eskey, D.E. (Eds.) (1988). Interactive Approaches to Second Language Reading. Cambridge: CUP.

[15] Carrell, P.L. \& Eisterhold, J.C. (1983). Schema theory and ESL reading pedagogy. TESOL Quarterly, 17(4), 553-573.

[16] Celce - Murcia, M. (1991). Teaching English as a second or foreign language. Massachusetts: Heinle \& Heinle publishers.

[17] Chamot, A.U. (2005). Language learning strategy instruction: Current issues and research. Annual review of Applied Linguistics, 25, $112-130$.

[18] Cook, G. (1989). Discourse in language teaching: A scheme for teacher education .Oxford: Oxford University Press.

[19] Elley, W. B. (1991) Acquiring literacy in a second language: the effect of book-based programs. Language Learning 41(3) 375-411.

[20] Ellis, R. (1997). Second Language Acquisition. Oxford. Oxford University Press.

[21] Eskey, D. (1970). A new Technique for teaching reading to advanced students. TESOL Quarterly, 4(4), 315-321.

[22] Faerch, C., \& Kasper, G. (1983). Strategies in interlanguage communication. London: Longman.

[23] Haastrup, K. (1989). Lexical inferencing procedures, Part 1 and Part 2. Copenhagen :Handelshojskolen i Kobenhavn.

[24] Garner, R. (1987). Metacognition and reading comprehension. Norwood, NJ: Ablex

[25] Grabe, W., \& Stroller, F. L. (2002). Teaching and researching reading. Harlow, UK: Longman.

[26] Grabe, W. 1991. Current Developments in Second Language Reading Research. TESOL Quarterly 25(3) 375-406.

[27] Guthrie, J., \& Wigfield, A. (1999). How motivation fits into a science of reading. Scientific Studies of Reading 3, 199-205.

[28] Krashen, S. D. (1989). We acquire vocabulary and spelling by reading: Additional evidence for the input hypothesis. The Modern Language Journal, 73, 440-464.

[29] Mayer, R. E. (1994). Visual aids to knowledge construction. In Wolfgang Schontz\& Raymond W. Kulhavy (Eds.), Comprehension of Graphics (pp.120-134). North - Holland : Elsevier Science B. V.

[30] Nagy, W. E., Herman, P., \& Anderson, R. C. (1985). Learning words from context. Reading Research Quarterly, 20, 233-253.

[31] Nation, P. (1997). The Language learning benefits of extensive reading. The Language Teacher, 21(5)13-17.

[32] Neil, J. A. (2007). Active skills for reading. Boston: Heinle Cenegage Learning.

[33] Pereira-Laird, J. A., \& Deane, F. P. (1997). Development and validation of a self-report measure of reading strategy use. Reading Psychology: An International Journal, 18, 185-235.

[34] Phakiti, A. (2006). Modeling cognitive and metacognitive strategies and their relationships to EFL reading test performance. Melbourne Papers in Language Testing, 1, 53-95.

[35] Pulido, D. (2009). How involved are American L2 learners of Spanish in lexical input processing tasks during reading? Studies in Second Language Acquisition, 31, 31-58.

[36] O’Malley, M.J., \& Chamot, A.U. (1990). Learning strategies in second language acquisition. Cambridge: Cambridge University Press.

[37] Ringler, L. H., \& Weber, C. K. (1984). A language -thinking approach to reading. San Diego: Harcourt Brace Jovanovich.

[38] Rivers, W., M. (1981). Teaching foreign language skills in a foreign language skills. Chicago: University of Chicago Press.

[39] Rodrigo, V., Krashen, S., \& Gribbons, B. (2004). The effectiveness of two comprehensible-input approaches to foreign language instruction at the intermediate level. System, 32, 53-60.

[40] Rumelhart, D.E., \& Ortony, A. (1977). The representation of knowledge in memory. In R.C. Anderson, R.J. Spiro \& W.E.
Montague (Eds.), Schooling and the acquisition of knowledge (pp. 99-135). Hillsdale, NJ: Erlbaum

[41] Taglieber, L. K., Johnson, L. L., \& Yarbrough, D. B. (1988). Effects of pre-reading activities on EFL reading by Brazilian college students. TESOL Quarterly, 22, 455-472.

[42] Tudor, I. (1989). Pre-reading: A categorization of formats. System, $17,323-328$.

[43] Vandergrift, L. (1999). Facilitating second language listening comprehension: Acquiring successful strategies. ELT Journal, 53 (3): 168-176.

[44] Wallace, C. (1992). Reading. Oxford: Oxford University Press.

[45] Zhang, L. J. (2008). Constructivist pedagogy in strategic reading instruction: Exploring pathways to learner development in the English as a second language (ESL) classroom. Instructional Science: An International Journal of the Learning Sciences, 36, 89-116.

\section{Appendix}

\section{3-2014}

Post Comprehension Test

\section{Name of the student \\ ID Number:}

\section{Subject area: Language Acquisition}

Level: 5

\section{Timing: 30 minutes}

Date:

\section{Decide whether the following statements are true or} false. Correct the false statements.

1. For innatists, repetition is necessary for effective language learning. ( )

2. Behaviorism and innatism explain the way people learn their L2. ( )

3 . Interlanguage refers to the language constructed by the learner. ( )

4. Feedback helps learners to test their hypothesis they form about the target language. ( )

5. Attitudes are beliefs that also involve learners' views about teachers and learning tasks. ( )

6. Aptitude is a general ability for learning a second language. ( )

7. The term acquisition explains how learners adapt to the new culture of the language they are learning. ( )

8. Output refers to the data to which learners are exposed.

( )

9. Contrastive analysis is used to describe learners' errors.

( )

10. Integrative motivation occurs when the learner's goal is functional. ( )

11. Avoidance is a reflection of language transfer. ( )

12. Field independent learners learn language analytically.

(13. Competence involves internalizing $\mathrm{L} 2$ rules and organizing them into a system. ( )

14. Recovering the rules form memory and using them naturally is referred to as Channel capacity.

15. Learning the second language is a conscious process. ( )

16. Linguists claim that intelligence is age-related. ( )

17. Communication strategies are similar to production strategies. ( )

18. It is claimed that introverted learners are more successful than extroverted learners in learning L2. ( )

19. Inhibition helps learners improve their pronunciation. ( )

20. Starting age affects the route of SLA. ( ) 